\title{
Er underslæb et faredelikt?
}

\author{
Af universitetsmanudukt $\phi r$, cand. jur. \\ BETH GROTHE NIELSEN, København
}

\section{Retssikkerhed og analogi.}

Det anses for et grundlæggende retssikkerhedshensyn, at et samfunds borgere har en reel mulighed for at finde ud af, om en vis adfærd er strafbar eller ej, hvilket forudsæller, at straffebestemmelserne er klart og entydigt affattede. Dette såkaldte legalitetsprincip anvendes undertiden som argument imod lovbestemmelser, der indeholder ubestemte og vurderingsprægede kriterier - således af straffelovrådet i dets begrundelse for ikke at kunne anbefale en generel regel om $\phi$ konomisk kriminalitet. ${ }^{1}$ )

Det strafferetlige legalitetsprincip antages at finde st $\varnothing$ tite i strfl. $\S 1,{ }^{2}$ ) der siger, at straf kun kan pålægges for et forhold, hvis strafbarhed er hjemlet ved lov, eller som ganske må ligestilles med et sådant. Et forhold er med andre ord kun strafbart, hvis det er omfattet af en lov, eller der er en så ,h $\phi \mathbf{j}$ grad af lighed mellem de i loven beskrevne tilf ælde og det til påd $\phi$ mmelse foreliggende ... a at det ville bero på ren formalisme, om det ikke inddroges under strafansvaret ". ${ }^{3}$ ) Torp retfærdigg $\varnothing \mathbf{r}$ den for dansk strafferet særegne addgang til analogislutninger med, at udelukkelse af denne mulighed ,frister ikke blot til en generaliserende Affattelse af Straffebudene, men ogsaa til paa anden Maade at g $\phi$ re disses Afgræensning saa vag ved Henvisning til ganske sk $\phi$ nsmæssige Kriterier eller Tilf $\varnothing$ jelser som „eller lignende“, at det i Virkeligheden bliver del samme paa en anden Maade"..4)

Det synspunkt, at loven skal angive n $\varnothing$ jagtige grænser for det strafbare område, kan vanskeligt gennemf $\phi$ res konsekvent, hvilket straffeloven bærer tydelige præg af. I de objektive gerningsindhold indgår en række mere eller mindre vage kriterier (retlige standarder), hvilket er en f $\phi$ lge af, at det ville være en uhyre vanskelig opgave i detaljer at beskrive samtlige de situationer, der skal dækkes af en bestemmelse. ${ }^{5}$ )

Imidlertid fastholdes princippet så vidt muligt, hvad angår

1) Straffelovrådets udtalelse om økonomisk kriminalitet af 14. januar 1974 , p. 27 ff. og p. 38 ff., jfr. også rådets udtalelse af 9. maj 1973.

2) Bl. a. af straffelovrädet i ovennævnte udtalelse af 9. maj 1973.

3) Stephan Hurwitz: Den danske Kriminalret, Almindelig del ved Knud Waaben, p. 89.

4) Carl Torp: Betænkning og Udkast til Love vedrørende den borgerlige Straffelovgivning, Kbh. 1917, motiver p. 5.

$\left.{ }^{5}\right)$ Se hertil fx. W. E. von Eyben: Kriminalrettens retlige standarder, N.T.f.K. 1951,294 ff., og Alf Ross: Forbrydelse og Straf, 1974, p. $10 \mathrm{ff}$. 
den objektive beskrivelse af det kriminelle område, og de ulemper i form af ,huller“ i loven, som de skarpe af grænsninger medf $\varnothing \mathrm{rer}$, kan man s $\phi$ ge afhjulpet ved at bruge adgangen til analogislutninger. Denne mulighed opfattes også af Hurwitz øjensynlig som en slags modvægt mod lovgivers eventuelle tilb $\varnothing j e-$ lighed til at gøre gerningsindholdene vage og udflydende, noget han ser som en fare for retssikkerheden. ${ }^{6}$ ) Dog udtrykker Hurwitz i forbindelse med sin gennemigang af berigelsesforbrydelserne stor betænkelighed ved overhovedet at basere et sitrafansvar på analogi. ${ }^{7}$ ) Retspraksis er da også tilbageholdende på dette område, og der foreligger, så vidt ses, intet højesteretspræjudiktat for analogisk anvendelse af en straffehjemmel. Derimod findes der eksempler på, at de lavere instanser har dømit efter en analogi, mens højesteret har fundet forholdet omfattet af loven uden at citere $\S 1$ - altså efter en fortolkning af vedkommende bestemmelse. ${ }^{8}$ ) Ved på denne måde at undgå ,den betænkelige adgang“ til analogi bliver retssikkerheden næppe bedre tilgodeset.

Legalitetsprincippet, som det kommer til udtryk i kravet om fuldstændig lovanalogi, må gælde med hensyn til enhver omstændighed, der betinger et forholds strafbarhed, herunder også de subjektive betingelser.9) Når en adfærd ved fortolkning (eller analogi) er subsumeret under et $i$ en straffebestemmelse beskrevet gerningsindhold, er det n $\phi$ dvendigt nærmere at vurdere den subjektive indstilling, der ligger bag denne objektivt retsstridige adfærd. Straffeloven opstiller generelt et krav om forsæt, idet uagtsomhed iflg. § 19 kun straffes, når det er særlig hjemlet. Hvad forsæt (og uagtsomhed) er, tager loven derimod ikke stilling til.

\section{Berigelsesforsæt.}

Når der i strfl. kap. 28 om berigelsesforbrydelser intet nævnes i de enkelte bestemmelser om, hvilken art af tilregnelse der kræves, betyder dette i f $\varnothing$ lge $\S 19$, at kun forsætlige overtrædelser er strafbare.

Foruden forsæt til de enkelte elementer i gerningsindholdet kræves det i de fleste af kapitlets bestemmelser, at gerningsmanden har handlet ,for at skaffe sig eller andre uberettiget

6) Stephan Hurwitz: op.cit., p. 90.

$\left.{ }^{7}\right)$. Samme: Kriminalret, Speciel del, p. 426 f.: „Strafansvar baseret på analogi bør —om den betænkelige adgang hertil i strfl. § 1 overhovedet benyttes — kun forekomme som en sjælden undtagelse og kun med henblik på tilfælde, der frembyder en til identitet grænsende lighed med de af lovbestemmelsen udtrykkelig omfattede".

${ }^{8}$ ) Se fx. UfR 1934.7119 H, forhandlinger på et i statsministeriet af statsministeren indkaldt møde antaget at være omfattet af strfl. $\$ 129$.

9) Stephan Hurwitz: Alm. del, p. 89. 
vinding““ ${ }^{10}$ ) Dette krav defineres af Hurwitz som ,forsæet til tilvejebringelse af uberettiget vinding gennem materiel krænkelse af formuefordelingen“, og berigelsesforbrydelser beskrives i det hele som ,forbrydelser, hvorved uberettiget vinding opnås direkte gennem retsitridig tilf $\varnothing$ jelse af et tilsvarende formuetab for den forurettede".,11)

Hvad der er det fælles kendemærke for berigelsesforbrydelserne, og hvori det subjektive krav til berigelsen egentlig består, har været stærkt omdiskuteret i ældre teori ( $\emptyset$ rsted, Bornemann, Goos, Torp). Resultatet af diskussionen blev en enslydende formulering $i$ de tre straffelovsudkast. Vendingen ,for derved at skaffe sig eller andre uberettiget vinding" forklares i motiverne som ensbetydende med vindingshensigt (berigelseshensigt), hvilket nærmere beskrives som en skærpet grad af forsæt. Berigelsen skal være tilstræbt. Der kræves en ud over forsættet rækkende hensigt. ${ }^{12}$ )

Også senere teoretikere går ind for dette synspunkt. Mens Krabbe er lidt i tvivl om sin stilling (til trods for at han var medforfatter til det sidste straffelovsudkast), ${ }^{12 a}$ ) synes Kirchheiner at antage, at der gælder et absolut krav om egentlig berigelseshensigt. Han mener imidlertid, at der kan påvises ,en vis praktisk Trang til Revision ....., saaledes at almindeligt Forsæt (min. udh.) med Hensyn til Forbrydelsesbegrebernes objektive Bestanddele anses for tilstrækkeligit". ${ }^{13}$ ) Hurwitz har formentlig misforstået Kirchheiner, idet han tager ham til indtægt for sin egen videre opfattelse af berigelseskravet. ${ }^{14}$ ) Han forklarer den anvendthe vending (,for at skaffe sig ....") som et udslag af, at fuldbyrdelsesmomentet er rykket frem, og ikke som udtryk for et skærpet forsætskrav, selv om den rent sproglige formulering

10) § 282 taler om at ,opnå eller betinge en ydelse, der står i væsentligt misforhold til modydelsen", hvilket ifølge motiverne (se især Carl Torp: op.cit. p. 232 og 171) ikke ændrer ågerforbrydelsens karakter af berigelsesforbrydelse.

$\S 284$ drejer sig om den, der , skaffer sig eller andre del i en ... vinding“, og den, som ,virker til at sikre en anden udbyttet....". Нæleribestemmelsen opfattes som en berigelsesforbrydelse allerede i kraft af placeringen i kap. 28 (se nærmere Stephan Hurwitz: Spec. del, p. 496).

$\S 289$ henviser til skattekontrollovens $\S 13$ stk. 1, der taler om ,forsæt til at unddrage det offentlige skat", hvilket vel også må forstås som et berigelsesforsæt.

11) Stephan Hurwitz: Spec. del, p. $366-67$.

12) Carl Torp: op.cit., p. 31 og p. 235. Straffelovskommissionens betænkning af 1923, sp. 68. Se i det hele Knud Waaben: Det kriminelle Forsæt, p. 219 ff., især p. 224.

12a) Oluf H. Krabbe: Borgerlig Straffelov, 4. udg., p. 142-43.

13) K. Kirchheiner: Nogle Bemærkninger om Bedrageri og Underslæb, N.T.f.S. 1941, 1 ff., især p. 44.

14) Stephan Hurwitz: op.cit., p. 367 med note 2 og p. 417 med note 8. 
kunne „synes at indebære en indsnævring af det almindelige forsætsbegreb". ${ }^{15}$ ) Han påpeger vanskelighederne ved en generel definition af berigelseskravet og siger, at ,,vægten må lægges på en real unders $\phi$ gelse af, hvor vidt de enkelte forbrydelsesbegreber bør strækkes, og der må her være plads for en varierende betydning af berigelseskravel", ${ }^{16}$ ) et synspunkt, som Waaben fremhæver det værdifulde $i$. Waaben er enig $i$, at der på trods af straffelovens forarbejder ikke kan fastholdes et krav om egentlig berigelseshensigt. ${ }^{17}$ )

I dag står teorien således på det standpunkt, at området for strafbare berigelsesforbrydelser omfatter andet end, hvad der subjektivt er båret af den $h \phi j e s t e$ grad af forsæt i relation til selve berigelsen. Problemet bliver herefter at finde grænsen nedad mod blot uagtsomhed. Tilregnelsesformerne defineres som sagt ikke i straffeloven, men betænkningen af 1923 indeholder i $\S 19$ stk. 2 en sålydende bestemmelse: „Forsæit foreligger, naar Gerningsmanden ved sin Handling vil hidføre, hvad der efter Loven kræves til Forbrydelsen, eller anser dennes Inditræden som en n $\varnothing$ dvendig eller overvejende sandsynlig F $\not$ lge af Gerningen eller vel kun anser Forbrydelsens Indtræden som mulig, men ville have handlet, selv om han havde anset den som sikker".

Teorien søger at opveje mangelen på en legal definition af forsætskravet ved med udgangspunkt $i$ retspraksis at fastlægge forsættets indhold, i.det der "ikke gives noget "naturligt" forsæitsbegireb som med en eller anden form for bindende virkning kan sættes ind i normsystemet". ${ }^{18}$ ) Man or blevet stående ved tre grader af forsæt: direkte forsæit eller hensigt, hvilket ved forårsagelsesdelikter vil sige, at ,gerningsmanden ved sin handling har tilstræbt (villet, tilsigtet at hidf $\phi$ re) den f $\phi$ lge, som hører til gerningsindholdet“, sandsynlighedsforsæt, hvilket vil sige, at ,en f $\varnothing$ lges indtræden .... er antaget med en sandsynlighedsgrad, der overstiger $50 \%$ ", og endelig dolus eventualis i form af den såkaldite positive indvilligelsesteori, hvorefter det for forsæet afgørende moment er, om gerningsmandens ,vilje bag den udviste adfærd har været af en sådan art, at han kan siges at have

15) Samme: Alm. del, p. $234 \mathrm{f}$. og Spec. del, p. 367. Knud Waaben: op.cit. p. 9. Det skal bemærkes, at Hurwitz i 1. udg. af Alm. del, 1952, p. $337 \mathrm{f}$., endnu synes at indtage det standpunkt, at der må tillægges udtrykket ,for at" i strfl. kap. 28 betydning som udtryk for en kvalificeret subjektiv ansvarsbetingelse - et skærpet forsætskrav.

16) Stephan Hurwitz: Spec. del, p. $368 \mathrm{f}$.

$\left.{ }^{17}\right)$ | Knud Waaben: op.cit., p. $224-25$, hvor det tilf $\varnothing j e s$, at synspunktet ,næppe ville være til hinder for en sammenlignende og sammenfattende drøftelse af de grundbegreber som utvivlsomt gør sig gældende gennem hele kap. 28“. Se også Knud Waaben: Strafferettens specielle del, hæfte 2, 1975, p. $76 \mathrm{f}$.

18) Samme: Det kriminelle Forsæt, p. 43. 
indvilget $\mathrm{i}$ eller accepteret den pågældende eventualitet også for det tilfælde, at den virkelig indtræeder"..19)

I overensstemmelse med denne almindelige lære om forsættets græniser foreligger der berigelsesforsæet, når gerningsmanden har tiil hensigt at skaffe sig en $\phi$ konomisk vinding gennem et tilsvarende tab for offeret, dvs. når der er hensigt til at påføre offeret en skade. Herudover antages forsæt, når gerningsmanden anser det for overvejende sandsynligt, at den vinding, han tilstræber, vil påf $\phi$ re offeret en skade $\mathrm{i}$ form af фkonomisk tab. Endelig statueres forsæt, når gerningsmanden har indset skademuligheden, dvis, risikoen for, at offeret vil lide tab, og i фvrigt har accepteret, at denne risiko virkelig kunne blive realiseret. Derimod or der $i k k e$ tale om forsæt, såfremt man må lægge til grund, at gerningsmanden nok har indset skademuligheden, men har handlet ud fra den overbevisning, at der ingen skade ville ske. Der kan højst blive tale om bevidst uagtsomhed i relation til skaden, altså det $\varnothing$ konomiske tab.

\section{Underslæb.}

Strfi. § 278 stk. 1 lyder: „For underslæb straffes den, som for derigennem at skaffe sig eller andre uberettiget vinding 1) tilegner sig en fremmed rørlig ting, dor er i hans varetægt ...", og „3) uretmæssigt forbruger ham betroede penge, selv om han ikke var forpligtet til at holde disse afsondrede fra sin egen formue". Denne objektive beskrivelse af det strafbare område opfylder vel i acceptabel grad legalitetsprincippets krav om klarhed og utvetydighed $\mathrm{i}$ formuleringen. Hvis man imidlertid vil vide noget om grænserne for strafbart underslæb, kan man ikke n $\phi$ jes med at studere ordlyden af $\S 278$. Den hellt afg $\phi$ rende betingelse, nemlig hvor grænsen for forsæt til berigelse går, finder man intet om her. Hvis man derefter vender sig til teoriens fremstilling af de subjektive betingelser for strafansvar, når man frem til de tre ovenfor beskrevne grader af forsæt. På basis heraf ville man komme til det resultat, at underslæb er straffrit, hvis gerningsmanden alene har indset muligheden (risikoen) for, at hans stræben efter $\phi$ konomisk vinding kunne påf $\varnothing$ re en anden et formuetab, men har regnet med, at det nok ikke ville gå så galt.

Praksis er næppe $\mathrm{i}$ overensstemmelse hermed.

I en række tilfælde ligger beviset for berigelseshensigt (direkte forsæt) klart. Meningen med tilegnelsen er at beholde tingen eller forbruge pengene uden vilje til senere at udrede et tilsva-

19) Stephan Hurwitz: Alm. del, p. $225 \mathrm{ff}$. Det skal bemærkes, at Alf Ross i Forbrydelse og Straf, 1974, vil påvise, at hensigt ikke er en forsætsform, og at dolus eventualis er et vildskud. Der skal ikke her tages stilling til disse teoriers holdbarhed, men blot henvises til Knud Waabens kritik i UfR 1975 B 1 ff. 
rende bel $\varnothing \mathrm{b}$, og hensigten undenstreges $\mathrm{fx}$. af, at gerningsmanden har udfærdiget falske bilag for at skjule dispositionerne.

Sagen stiller sig noget anderledes i de tilfælde, hvor gerningsmanden har haft vilje til - sandsynliggjont ved det for retten oplysite - at opfylde de forpligtelser, han har pådraget sig ved sine odi $\phi$ se transaktioner, men mere eller mindre ringe evne (udsigt) til faktisk at g $\varnothing \mathrm{re}$ det. I denne situation bliver den anden grad af fonsæt, sandsynlighedsforsæt, aktuel. Objektive kendsgenninger, som at tab faktisk er inidtrådt, og at det bagefter er let (for andre) at se, hvordan det ville gå, beviser ikke, at også gerningsmanden havde indset skaden (offerets tab) som en overvejende sandsynlig f $\phi$ lge af sine handlinger, men vil veje tungt i den samlede bevisvurdering. Det skal bemærkes, at der selvf $\phi$ lgelig er specielle vanskeligheder forbundet med at bevise et forsæt, idet noget subjektivt ikke kan være ,genstand for en umiddelbar objektiv konstatering“ ${ }^{20}$ ) Waaben beskriver domstolenes metode som ,en kriitisk anvendelse af almindelig psykologisk erfaring“. „På grundlag af samtlige oplysninger om den påståede forbrydelses objektive side skal der dannes en opfattelse af den subjektive. Den må ikke blot udgøre en brugbar hypotese, men skal melde sig med en sådan styrke at der kan tales om bevis, - et bevis som principielt ikke må være svagere end beviset for det objektive". (Min udh.). ${ }^{21}$ )

Strafansvar for underslæb baseret på det også i teorien almindeligt anerkendte sandsynlighedsforsæt er statueret i en række domme. ${ }^{22}$ ) Mere problematiske er de sager, hvor endnu lavere forsætsgrader synes at være lagt til grund. Som typetilfælde kan nævnes tre grupper:

1. tilfælde, hvor offeret led et $\phi$ konomisk tab, der ikke blev dækkket inden dom.

2. tilfælde, hvor offerets tab erstattedes af gerningsmanden umiddelbart efter opdagelsen.

3. tillfælde, hvor offeret intet tab havde lidt ved opdagelsen.

De synes alle at være karakteriseret af, at gerningsmanden måske nok har opfattet en vis risiko (skademulighed) for offeret, men er gået ud fra, at skaden ikke virkelig ville indtræde.

20) Knud Waaben: Det kriminelle Forsæt, p. 56.

21) p. 58. Se også Fuldmægtigen 1962, $147 \mathrm{ff}$, der refererer et foredrag af Erik Christensen om politiets efterforskning af det kriminelle forsæt, hvori det siges, at „i tilfælde af ikke-tilståelse kan eksakt bevis for forsæt ikke gives, men man må her bruge sin sunde fornuft.... Kriminalpolitiet interesserer sig først og fremmest for de objektive momenter; men det er ikke nok, at politimanden mener, at faktum klant indicerer, at der også har været forsæet til stede". Hermed understreges altså, at for politiet er bevis for gerningsindholdets objektive realisation ikke $i$ sig selv bevis for den subjektive tilregnelse. Disse betragtninger må så meget desto mere gælde for domstolenes vedkommende.

${ }^{22}$ ) Knud Waaben: op.cit., p. 280 og fx. de p. 281 omtalte domme. 
Ad gruppe 1.

I HRT 1936.622 var forholdet det, at to personer havde brugt et bel $\phi \mathrm{b}$ på $1.000,-\mathrm{kr}$., som deres salgschauff $\phi \mathrm{r}$ ved sin ansættelse havde stillet som sikkerhed for en vogn og nogle varer. Deres forklaring gik ud på, at de hele tiden havde ment at kunne klare tilbagebetalingen af pengene, hvis chauff $\phi$ rens ansættelsesforhold skulle oph $\phi$ re. Tilttalen gik ud på, at de ,til egen Fordel har forbrugt det nævnte Bel $\phi \mathbf{b} . .$. uagtet de .... indsaa eller maatte indse (min udh.), at de ville være ganske ude af stand til at tilbagebetale Bel $\varnothing$ bet". De d $\varnothing$ mites med den begrundelse, at ,,de begge har været klar over, at Beløbet .... indgik i Bageriets Drift og medgik til dets Driftsunderskud, og at de ikke bestemt kunne regne med ad anden Vej at komme i Besiddelse af et tilsvarende Belфb til Dækning (min udh.) af de $1.000 \mathrm{Kr}$. idet de efter det under Sagen oplyste maa antages at have været insolventte ....“. De id $\varnothing$ mtes ubetinget fængsel i 3 måneder.

Fra senere retspraksis kan nævnes UfR $1953.377 \varnothing$. Tiltalte havde indgået en overordentlig ugunstig kontrakt om salg af manufakturvarer. Under en sygdomsperiode, hvor salget gik dånligt, forlangte medkontrahenten, et k $\phi$ benhavnsk aktieselskab, at tiltallte skulle afholde udgifter til medhjælp, annoncering og modernisering af butikken af egne midler, hvilket hun ikke turde modsætte sig. Hun brugte imidlertid godt 6.000 , - kr. af de aktieselskabet tilkommende indbetalinger fra afbetalingskunder. Hun frifandites i underretten, idet hendes ,forklaring om, at hun, da hun indkasserede de her omhandlede bel $\phi \mathrm{b}$, regnede med, at firmaet „Bolette“ dels ved sikkerhedsdepotet, dels ved delcrederekontoen havde tilstrækkelig sikkerhed for bel $\phi$ bene, og at det var hendes hensigt at tilbagebetale bel $\varnothing$ bene, og at hun havde rimelig udsigt til at kunne g $\phi \mathrm{re}$ dette", ikke fandtes at kunne forkastes. Landsretten dømite imidlentid, da det ansås godtgjort, ,,at tiltalte, da hun forbrugte det i anklageskriftet omhandlede bel $\phi$ b, var klar over, at selskabet ikke havde dækning for dette ....“. På ginund af de nærmere omstæendigheder bortfaldit straffen i medf $\varnothing \mathrm{r}$ af $\S 287$ stk. 1.

Nævnes kan også JD 1937.76 (,,kritiklфst forbrug“ af aktieselskabsmidler i troen på, at firmaet ville give overskud), UfR 1957.1111 $\emptyset$ (sagførers anbringende om salærkrav) og UfR 1958.54 H (kasserer i menighedsråd).

Ad gruppe 2.

UfR 1961.588 H drejer sig om en sognerådsformand, der som kasserer for et fælleskommunalt alderdomshjem havde forbrugt ca. 14.300,- kr. af hjemmets midler, af hvilke dog senere 5.500 , - kr. var tilbagebetalt, og resten blev dækket dagen efter 
opdagelsen ved hjælp af et lån, som der allerede tidligere var indgået aftale om. Han havde i sin kasserertid ikke f $\varnothing$ rt særskilte bøger, men blot hævet penge på alderdomshjemmets konto efter et sk $\varnothing$ n over udgifterne. På et vist tidspunkt var han klar over, at han skyldite hjemmet et mindre beløb. Da han endelig blev afkrævet et regniskab første gang, opdagede han til sin overraskelse, hvor stort tilsvaret var. Underretten udtalte: „Selv om tiltalte ikke fønte noget regnskab dag for dag, findes det ubetænkeligt at statuere, at han må have været klar over, at han efterhånden havde et ikkke ringe tillsvar til alderdomshjemmet", og tilf $\varnothing$ jede: „Efter det om tiltaltes $\varnothing$ konomiske forhold oplyste, herunider særlig hans mangel på likvide midler, må det antages, at de penge, der således kom $\mathrm{i}$ hans besiddelse, af ham er forbrugt $i$ hans virksomhed, og at der herved er påf $\phi$ nt alderdomshjemmet en $\phi$ konomisk risiko". Lanidsret og h $\phi$ jesteret stadfæstede $i$ henhold tid de af underretten anf $\phi$ rte grunde.

Denne dom omtaler således direkte en rent objektiv risiko for $\phi$ konomisk tab uden at beskæftige sig med risikograden eller med tilitalites subjektive indstilling til denne risiko. Underretten ville gøre straffen betinget (dissens for ubetinget) bl. a. under hensyn til, at det tilvendite bel $\varnothing \mathbf{b}$ straks blev ersitattet, mens landsretiten med samme begrundelse ville nedsætte den af underretten udmålte straf af fængsel i 1 år til 8 måneder og gøre den ubetinget (dissens for betinget). Højesteret stadfæstede landsrettens afig $\phi$ relse, altså ubetinget fængsel i 8 måneder.

I UfR 1962.168 H forelå der en uforbeholden tilståelse, men af sagen fremgår det, at det også her drejede sig om almindelig uorden og manglende regnskabsmæssig forstand. Den tiltalte panitefoged var klar over denne uorden, men ikke over, hvor stort underskuddet var, og hans private $\phi$ konomiske forhold var hele tiden sådanne, at han hurtigt kunne skaffe dækning, hvilket også skete i løbet af et par dage efter opdagelsen. Muligvis på

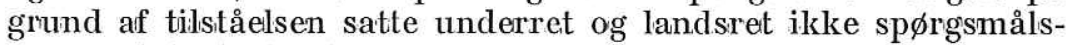
tegn ved berigelsesforsættet, men i h $\phi$ jesteret blev der nedlagt påstand om hjemvisning, idet sagen ikke burde have været behandlet efter rpl. §925, hvilken påstand højesteret dog afviste. I denne sag blev straffen på fængsel i 7 måneder gjont betinget, dog med dissens for ubetinget i såvel landsret som $h \phi$ jesteret.

Nævnes kan også UfR 1952.1004 H angående en deprimeret overbetjent, der i en periode på et par år undlod straks at indbetale nogle af ham indkasserede $b \phi d$ er til politikontoret, idet han først afregnede fra 2 til 9 måneder efter modtagelsen. Tiltaltes forklaring om ikke at have hafit til hensigt at berige sig, idet han altid havde haft penge til rådighed selv og forholdene alene skyldtes sl $\varnothing$ seri - en forklaring, der bestyrkedes af, at han af egne midler straks efter opdagelsen indbetalte restbel $\phi$ bet 
805, - kr. - blev forkastet, idet underretten uditalte, at ,hans evne til at tilbagebetale beløbene ikke betager forholdet dets strafibare krarakter". Også landsret og højesteret statuerede berigelsesfor'sæt, men med en intetsigende begrundelse, idet man blot citerede lovens ord: „f for derigennem at skaffe ....“. ${ }^{23}$ ) Straffen på 3 måneders fængsel blev af højesteret gjort betinget.

Til denne gruppe kan også henf $\varnothing$ res UfR 1959.267 (forstander for ungdomshjem).

\section{Ad gruppe 3.}

I UfR $1957.649 \emptyset$ blev en sagf $\varnothing$ rerfuldmægtig d $\varnothing \mathrm{mt}$ for underslæb efter $\S 278 \mathrm{nr}$. 1, idet han fra sagf $\phi$ rerfirmaets pengeskab havde fjernet nogle obligationer, der tilh $\phi$ rte en klient. Disse lagde han som sikkerhed $i$ en bank for et lån, der skulle anvendes til fintansiering af en større ejendomshandel. Det fremgår af sagen, at der næppe på noget tidspunkt havde været andet end en rent teoretisk risiko for, at obligationerne ikke til enhver tid kunne indløses, og at tiltalte $\mathrm{i}$ hvent fald havde handlet ud fra en velbegrundet tillid til, at der ikke ville opstå risiko endsige tab for klienten. Faktisk gik handelen efter forventning, obligationerne blev lagt tilbage i pengeskabet, og f $\phi$ rst langt senere meldte sagf $\varnothing$ rerfuldmægtigen sig selv til politiet, „formentlig særlig under hensyn til det nervepres, han i den forl $\phi$ bne tid har været udsat for".

Dommen er, så vidt det kan bedømmes ud fra referatet, problematisk $\mathrm{i}$ to henseender. For det første synes kravet om tilegnelse at være fraveget, idet tilegnelsens såkaldt negative side, forsæettet til varigt at skille ejeren fra tingen, synes at mangle. Hurwitz nævner et tilsvarende problem med hensyn til pantsætning af fremmed ting $i$ egen varetægt $i$ den hensigt at indløse pantet $f \phi r$ forfaldstid og henviser til on frifindende dom (JD 1937.151), men tilf $\varnothing$ jer : „På den anden side må det till berigelsesforsæt ved denne gruppe af delikter normalt være tilstrækkeligt, at det står gerningsmanden klart, at han ved sin ulovlige disposition udsætter den berettigede for en særlig tabsrisiko, omend han ikke ligefrem har forsæt til at påf $\phi$ re ham tab" ${ }^{24}$ ) Hermed menes formentlig, at selve tilegnelseskravet kan fraviges, såfremt ,gerningsmanden har været klar over, at han uberettiget påf $\phi$ nte en anden en væsentlig risiko (forf. udh.) for formuetab““. ${ }^{25}$ )

I ovennævinte sag var der imidlentid for det andet næppe heller bevidsthed om tabsrisiko hos gerningsmanden. Landsretten udtalte da også, at ,det vel efter det foreliggende må antages, at

23), Dommen er kritiseret op.cit., p. 279-80.

24) Stephan Hurwitz: Spec. del, p. 415, der henviser til p. 367. Se også Knud Waaben: Strafferettens specielle del, hæfte 2., p. $100 \mathrm{f}$.

25) Stephan Hurwitz: op.cit., p. 367. 
tiltalte har haft en vis rimelig grund til at tro, at han med videresalg af „L фj.tvedgård“ inden for en kortere periode kunne skaffe kontante midler til veje til indfrielse af lånet i K $\phi$ bmandsbanken og dermed til frigivelse af kreditforeningsobligationerne ....“. Alligevel tilitrådtes det, at ,ttiltales tilegnelse af obligationerne må anses som en berigelsesforbrydelse, idet det måtte have stået tiltalte klart, at han har udsat ejerne af obligationerne for en $\phi$ konomisk risiko". Heller ikke i denne dom blev graden af risiko drøfitet. Tiltallte fik fængsel i 6 måneder ubetinget.

Herefter opsitår spørgsmålet, hvad der er tilbage af kravet om berigelsesforsæe. Hvis man tager udgangspunkt i den laveste forsætsgrad, den såkaldte dolus eventualis, der kræver, at gerningsmanden skal have indset skademuligheden (tabsrisikoen) og have handilet ud fra en positiv indvilligelse $i$ også i givet fald

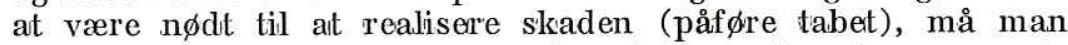
komme til den konklusion, at sagf $\phi$ rerfuldmægitigen i ovennævnte sag ikke handlede forsætligit, men i det $h \phi j e s t e ~ b e v i d s t ~ u a g t s o m i t$, idet han klant (og efter det oplyste med rimelig grund) gik ud fra, at den i sig selv fjerne risiko ikke ville blive aktuel.

Til denne sidste gruppe af domme kan muligvis også henf $\emptyset$ res UfR $1935.1126 \emptyset$.

De fleste trykte domme angående undersiæb inden for de seneste ti år er behandlet som tilståelsessager, hvorfor der ikke har været umiddelbar anledning til at drøfte forsætsproblemer, selv om det i nogle tilfælde af de meget kortfattede referater fremgår, at der kunne være tvivl om den subjektive side af sagen. Som eksempler kan nævnes UfR $1968.53 \mathrm{H}$, hvor tilltalte oplyste, at han regnede med at kunne betale tilbage af salget $i$ sin forretning, hvilket imidlentid i den pågældende periode dalede stærkt, og UfR $1970.745 \mathrm{H}$ om et landpostbud, der omhyggeligt opbevarede girokortene til de af ham tilbageholdte bel $\phi \mathbf{b}$ for senere at afsende pengene, hvilket dog kun lykkedes for en dels vedkommende inden opdagelsen. Ait der er en vis risiko for overfladisk vurdering af forsæitskravet med hensyn til berrigelsen, når et forhold behandles efter rpl. $\S 925$, fremgår fx. af den ovenfor under gruppe 2 nævnte sag, UfR $1962.168 \mathrm{H}$. Til illustration kan også anf $\phi$ res VLT 1956.43, hvor sagens behandling ved underretten ophævedes, idet tiltalte trods sin ,tilståelse“, i følge sin forklaring i $\phi$ vrigt, ikke havde haft til hensigt at skaffe sig uberettiget vinding.

I et par sager har tiltalte anf $\phi$ rt momenter til st $\phi$ the for en frifindelsespåstand, se fx. UfR $1968.652 \emptyset$ (modkrav $\mathrm{i}$ form af honorar) og UfR $1971.553 \varnothing$ (forglemmelse), der kunne rejse tvivl om berigelsesforsættet. Rettens stillingtagen til spфrismålet fremgår ikke af referaterne. Måske d $\varnothing$ mmer man på baggrund af en motivationsproces, som beskrives således af Waaben: „For 
den erfarme dommer er de fleste straffesager praktiske gentagelser af mange tidligere. Hans bevidste og ubevidste indstilling til en sag besitemmes af det som er hans viden om sager af denne art. Dommeren har dannet sig et typebillede - eller flere typebilleder - af en paragrafs område, og den konkrete vurdering af en vis adfærd vil hyppigt bestå $\mathrm{i}$ en usammensat praktisk erkendelse af adfærdens lighed med typen. .... Såsnart sagen rummer et væsentligt individuelt træk vil der hos dommeren vækkes en tendens til . . . a analyse, måske med sondring mellem objektive og subjektive elementer. .... Et anbringende om vilje og evne til fyldestg $\phi$ relse i en sag om underslæb eller bedrageri vil blive kritisk efterpr $\varnothing v e t$, hvorefter sagens faktiske sammenhæng vil blive målt med de normer som sædvanligt anlægges overfor personer i tilsvarende situationer. Muligt finder retten at denne målestok kan udtrykkes sprogligt i en almen sætning der gør brug af ord som ,nærliggende risiko“ el. lign., men det som dommeren har $\mathrm{i}$ tankerne er i hvert fald ikke det almindelige forsætsbegreb, men et billede af den objektive sammenhæng og subjektive indstilling som er utilladelig på dette (forf. udh.) område. .... i mange sager har dommerens overvejelser ikke speciel relation til forsætssp $\varnothing$ rgsmål; der antages mere ubevidsit en psykologisk normalitet $\mathrm{i}$ forhold till det objektive forl $\phi b^{\prime \prime} .{ }^{26}$ ) Underslæbssager af ovennævnte type har altså for dommeren næppe indeholdt sådanne individuelle træk, at tendensen til sondring mellem objektive og subjektive elementer er blevet vakt. Det objektive forl $\phi b$ afsl $\phi r e r$ efter den beskrevne betragtningsmåde $\mathrm{i}$ sig selv gerningsmandens subjektive indstilling.

\section{Risikoforsæt.}

De under gruppe $1-3$ refererede domme $g \phi r$ det formentlig berettiget at beskrive forholdet mellem loven og retspraksis således: Underslæbsbestemmelsen er i loven formuleret som et forsæatligt skadedelikt (forårsagelsesdelikt) med fremrykket fuldbyrdelsesmoment, hvilket betyder, at skaden (formuetabet) ikke faktisk behфver at være indtrådt, men skal være omfattet af germingsmandens forsæt. Praksis fremviser imidlertid en række eksempler på en grad af tilregnelse, der højst kan beskrives som bevidst uagtsomhed i relation til skadens indtræden, hvilket er i strid med strfl. $\S 19$. Hvis forsætskravet derfor skal opfyldes, må underslæbsbestemmelsen defineres som et (konkret) faredelikt, idet den bevidiste uagtsomhed med hensyn till formuetabet må siges at svare til forsætskravet ved et faredelikt.

Dette er mere end et spørgsmål om terminologi. Teoriens be-

26) Knud Waaben: Det kriminelle Forsæt, p. $51 \mathrm{f}$. 
greber tjener til at generalisere og analysere praksis. Som fremhævet af Waaben, må det være ,,en særlig vigtig opgave [for teorien] $\ldots$ at advare mod udglidende forsætskrav" (min udh.). ${ }^{27}$ ) Men det ser ud til, at teoretikerne uden videre har godtaget det af praksis indf $\varnothing$ rte kriterium på berigelsesforsæt, forsæit til risiko for tab.

I sin kommenterede straffelov uditaler Krabbe om berigelseskravet, at det ,er en selvf $\phi$ lgelig Forudsætning, at der hos Gerningsmanden foreligger Berigelseshensigt, saa at Straf er udelukket, naar Gerningsmanden har haft F $\phi$ je til at antage, at hans Dispositioner ikke ville paaf $\varnothing \mathrm{re}$ den berettigede Tab“, og med hensyn til de objektive momenter i $\S 278 \mathrm{nr}$. 3, forbrugets uretmæssige og tabvoldende karakter, at ,„.. Gerningsmanden if $\varnothing$ lge Retsforholdets Beskaffenhed maatte anses forpligtet til at holde enten selve det moditagne eller et hertil svarende Bel $\varnothing \mathrm{b}$ til den berettigedes Disposition, saaledes at Forbruget ikke gor den berettigedes Interesse usikker" (forf. udh.), hvilket så vidt ses er det nærmeste, Krabbe kommer til et risikosynspunkt. ${ }^{28}$ )

J $\varnothing$ rgen Trolle omtaler i sin anmeldelse af Krabbe ${ }^{20}$ ) spørgsmålet, idet han finder det, ,rigtigt at bemærke, at Praksis i hvert Fald forsaavidt angaar Sagf $\phi$ reres Forbrug af betroede Midler ikke til Forbrydelsens Fuldbyrdelse kræver, at Tab faktisk skal være lidt, men anser det tilstrækkeligt, at Forbruget har medf $\phi \mathbf{r t}$ en virkelig Risiko (min udh.) for, at saadant Tab skal lides". Herved understreges imidlertid $\varnothing$ jensynlig blot bestemmelsens fremrykkede fuldbyrdelse, og der anf $\varnothing$ res - ligesom hos Krabbe - intet om det subjektive krav i forbindelse med denne risiko.

I afsnittet, der indleder formu eforbrydelserne i Hurwitz's Speciel $\mathrm{del}^{30}{ }^{30}$ ) siges det: „I visse relationer må det være tilstrækkeligt, at gerningsmandien har været klar over, at han uberettiget påf $\phi$ rte en anden en væsentlig risiko (min udh.) for formuetab“, og der henvises i en note til Kirchheiner, der imidlentid — som ovenfor anf $\phi \mathrm{rt}$ - næppe påviser andet end et behov for at fravige kravet om „,berigelseshensigt i selve lovteksten som et kvalificeret forsæt" ${ }^{31}$ ) således at de lavere forsætsgrader incl. dolus eventualis bringes i anvendelse. Det er uklart, om Kirchheiner i virkeligheden mener, at allerede denne udvidelse af det subjektive krav n $\phi$ dvendigg $\phi r$ en lovændring. ${ }^{32}$ )

I kapitlet om underslæb taler Hurwitz om „særlig tabsrisiko“ og "alvorlig tabsrisiko" (mine udh.) ${ }^{33}$ ) uden nærmere diskus-

27), Op.cit., p. 48.

28) Oluf H. Krabbe: op.cit., p. $672-73$.

29) Juristen $1948.298 \mathrm{ff}$., især p. 302.

30) Stephan Hurwitz: op.cit., p. 367.

31). K. Kirchheiner, op.cit., p. $11-12$ og p. 44.

32) Op.cit., p. $17-18$.

33) Stephan Hurwitz: op.cit., p. 415 og p. 417. 
sion, og i afsnittet om bedrageri, der i modsætning til underslæb i f $\varnothing$ lge bestemmelsens ordlyd kræver, at formuetab faktisk skal være indtrådt, altså ikke har fremrykket fuldbyrdelsesmoment, siger Hurwitz generelt om formuetabet ved berigelsesforbrydelserne: „I klasse med indtrådt tab må i mange tilfælde stilles en vis fare for tab" (min udh.). Han tilf $\varnothing$ jer: „Dette er i praksis også antaget med henblik på bedrageri uanset ordlyden af $\S 279$. Trods betænkeligheder ved en fravigelse eller udvidende fortolkning af den legale definition af gerningsindholdet må denne retspraksis accepteres som stemmende med lovens forudsætninger og som realt velbegrundet",${ }^{34}$ ) hvilket altså antyder betænkelighed med hensyn til denne fravigelse af de objektive krav. I фvrigt har han næppe ret $i$, at denne praksis stemmer med lovens forudsætninger. Som fremhævet ovenfor er det i hvert fald i strid med dens forarbejder.

Hurwitz diskuterer heller ikke i forbindelse med bedrageriforbrydelsen det subjektive rekvisit, risikoforsættet, nærmere. Denne mangel kritiseres af $\mathrm{H}$. Olafsson i hans anmeldelse af Speciel del $^{35}$ ) idet han udtaler: „Disse spфrgsmål om de subjektive betingelser ved berigelsesforbrydelser er iøvrigt af så stor praktisk betydning, at man kunne have $\phi$ nsket sig en noget mere dybtgående behandling.". ${ }^{35 a}$ )

I „Det kriminelle Forsæt“ fremhæver Waaben ved gennemgangen af berigelsesforsættet, at således som en række refererede domme er formuleret, peger de på problemet, ,om der blot kræves et fareforsæt som svarer til bevidst uagtsomhed i relation til følgen“" ${ }^{36}$ ) Med henblik på at fastslå, hvor forsætsgrænsen går, tager Waaben, så vidt ses, udgangspunkt i dolus eventualis, men understreger det praktisk umulige i at ,skelne skarpt mellem tilfælde hvor $\mathrm{T}$ trods $\phi$ konomiske vanskeligheder har haft en sikker tro på den senere betalingsevne og tilfælde hvor han har erkendt, at det kunne gå galt" (forf. udh.). Sondringen har efiter hans mening næppe st $\varnothing$ rre interesse, men det tilf $\varnothing$ jes: „Det skulle være ubetænkeligt at fastslå at visse grader af stærk, sk $\varnothing$ nt ikke aldeles sikker forventning om senere midler udelukker forsæt. Det er uantageligt at de omhandlede gerningstyper blot skulle kræve et forsæit af den art som kendes ved visse faredelikter". Dernæst nævnes forventninger om fremtidige indbetalinger og

34) Op.cit., p. 454 .

35) Juristen $1957.67 \mathrm{ff}$., især p. 82.

35a) Se også Kommenteret straffelov, Speciel del, 1975, p. 311. p. $326 \mathrm{f}$. findes f $\varnothing$ lgende bemærkning: ,Det forekommer i $\varnothing v$ vigt ikke sjældent ved $\S 278$, at en handling, hvorved gerningsindholdet objektivt realiseres, ikke er foretaget med det forn $\varnothing$ dne berigelsesforsæt". Det er usikkert, hvorledes dette skal forstås.

36) Knud Waaben: op.cit., p. 283. 
overbevisning om allerede disponible værdier som eksempler på, at berigelsesforsæt kan være udelukket. Idet det erkendes, at man kommer i forlegenhed, hvis man i en kort formel skal angive den forsætsgrænse, som danske domstole regner med, opstilles to mulige kriterier: at kræve en overvejende sandsynlighed eller en væsentlig risiko for f $\varnothing$ lgen, og det tilf $\varnothing \mathrm{jes}$, at af disse to muligheder stemmer ",vistnok" den sidste bedst med retspraksis.

Waaben peger på nogle fordele ved kriteriet „overvejende sandsynlighed“, idet det ,,jo antagelig [er] hovedreglen om forsæt i dansk ret". Desuden vil man ,herved fjerne sig mindst fra strfl.s forarbejder“, og der ligger ,gennemgående .... den sikreste vejledning i kravet om overvejende sandsynlighed". „... . en dolus eventualis-lære kunne ramme nogle af de tilfælde, der ligger under den almindelige grænse". Imidlertid mener Waaben, at „bevismæssige og præventive hensyn g $\phi r$ det .... noget betænkeligt at bestemme forsættet på denne måde“, idet det kan være svænt at sk $\varnothing$ nne, hvornår noget er overvejende sandsynligt. „Når risikoen er evident og betydelig (min udh.) kan det f $\phi$ les urimeligt hvis denne tvivl .... skal bevirke frifindelse eller føre over $\dot{i}$ en dolus eventualis-afvejelse som det formentlig $i$ det hele ligger domstolene fjernt at gennemf $\varnothing$ re efter teoretiske linier". „,... det synes berettiget at se noget centralt netop i fremkaldelsen af en kvalificeret fare". Det påpeges derefter, at vore forestillinger om forsætsgrænsen bygger på eksempler fra drabsforbrydelsen og de derfra adskilte bestemmelser angående fremkaldelse af livsfare. Man kan godt tænke sig, at flere faregrader lægges sammen til én gerningstype på andre områder, og berigelsesforbrydelserne synes netop at være et område, hvor det er ,,berettiget at regne med een gerningstype fra det punkt på skalaen hvor der er tale om en virkelig betydelig risiko (min udh.) for andres $\phi$ konomiske interesser" ${ }^{37}$ )

Waaben synes således at have placeret det af retspraksis anerkendte risikoforsæt som en grad af tillregnelse, hvis grænse ligger lavere end sandsynlighedsforsættet, men h $\phi j$ jere end dolus eventualis. At have indset, at man ved sine dispositioner udsætiter en anden for en væsentlig risiko for formuetab for selv at kunne opnå en (uberettiget) vinding, skulle i følge denne teori ikke kunne beskrives ved hjælp af den mulighedskonstruktion, teorien plejer at anvende til at forklare indholdet af forsætsgraden dolus eventualis $\mathrm{i}$ form af den positive indvilligelsesteori. ${ }^{38}$ ) Dette kan være en rigtig konsekvens, sålænge man lægger vægit på, at risikoen skal være væsentlig. (Som det vil fremgå, benytter Hurwitz i flæng ordene væsentlig, særlig, alvorlig, men taler også om en vis risiko, og Waaben anvender i „Det kriminelle Forsæt“ des-

37) Op.cit., p. $286 \longrightarrow 90$.

38) Stephan Hurwitz: Alm. del, p. $229 \mathrm{ff}$. 
uden udtrykkene evident og virkelig betydelig, mens han i Strafferettens specielle del, hæfte 2, konsekvent bruger udtrykket væsentlig risiko). Af g $\phi$ relsen af, om en risiko har været så væsentlig, at der b $\phi \mathbf{r}$ ifaldes strafansvar, må så baseres på en vurdering af de objektive $\phi$ konomiske kendsgerninger på gerningstidspunktet og en vis tid fremover samt på en begrundet antagelse af, at gerningsmanden har vurderet risikoen nogenlunde tilsvarende.

Hvis man derimod afsvækker kravet til risikoens størrelse, som det synes at være sket i flere af ovennævnte domme (således klarest i UfR 1952.1004 H (overbetjenten), UfR $1957.649 \emptyset$ (sagf $\phi$ rerfuldmægitigen), UfR 1961.588 H (sognerådsformanden) og UfR $1962.168 \mathrm{H}$ (pantefogden)), nærmer man sig, som også fremhævet af Waaben, ${ }^{39}$ ) det rene formaldelikt (eller faredelikt). Når sådanne kvalificerede tillidsbrud, som det fortrinsvis synes at dreje sig om, faktisk straffes, kommer man næppe uden om at forklare afg $\phi$ relserne ved hjælp af dolus eventualis-betragtninger. Den objektivt set minimale risiko, der har foreligget, er endda næppe $\mathrm{i}$ alle tilfælde af gerningsmanden indset som en tabsmulighed overhovedet. $\mathrm{Og}$ da det $\mathrm{i}$ hvert fald symes temmelig betænkeligt at forkasite de tiltaltes anbringender om ikke at have anset en eventuel mulighed for at kunne blive faktisk virkelighed, kan end ikke et dolus eventualis-ansvar i den positive indvilligelses form med rimelighed statueres, idet der ikke her skal tages stilling til, hvilket resultat man ville komme til efter den hypotetiske prøve, som - på trods af ordlyden i de to sidste straffelovsudkast - ikke anerkendes i dansk teori og (formentlig) heller ikke i praksis. ${ }^{40}$ ) Man kan herefter - som ovenfor fremhævet - kun forklare dommene som udslag af, at $\S 278$ i tidens l $\phi \mathrm{b}$ er blevet omdefineret til et forsætligt faredelikt.

\section{Analogi og retssikkerhed.}

Som indledningsvis omtalt åbner strfl. § 1 mulighed for at anvende en bestemmelse analogisk på et forhold, der ,ganske må ligestilles" med det af loven direkte omfattede - den såkaldite fuldstændige lovanalogi. Man kunne da spørge, om ikke det var muligt i relation til skaden i $\S 278$ analogisk at udvide denne til at omfatte fare, med den begrundelse, at der er n $\varnothing$ jagtig samme behov for at straffe den forsætlige fremkaldelse af $\phi$ konomisk risiko som den forsætlige tabforvoldelse. Man må dog nok afvise denne lфsning som værende en partiel analogi, hvorom Hurwitz udtaler: „Det er udelukket at anvende en såkaldt ufuldstændig eller partiel analogi, hvorefter et med lovens tilfælde beslægtet, men mindre graverende forhold rammes af en for-

39) Knud Waaben: op.cit., p. 291.

so) Stephan Hurwitz: op.cit., p. 229 ff. Knud Waaben: op.cit., 352 ff. 
holdsmæssig mindre straf.“" ${ }^{41}$ ) Det samme ville være tilfældet blot endnu klarere - hvis man analogiserede fra $\S 19$ 's krav om skadeforsæt (berigelsesforsæt) i $\S 278$ til bevidst uagtsomhed i relation til tabet.41a)

Det føles i strid med de ovenfor beskrevne retssikkerhedshensyn, at retspraksis på underslæbsområdet synes at hvile på en så tvivlsom hjemmel, at end ikke straffelovens $\S 1$ kan legitimere den.

\section{De lege ferenda.}

Ved valget af gerningsbeskrivelse kan lovgiver kriminalisere selve handlingen, den fremkaldte fare eller den realiserede følge, således at det strafferetlige værn gøres mere eller mindre effektivt. Med hensyn til beskyttelsen af den legemlige integritet opregner straffeloven en række stadier fra den blotte abstrakt farlige handling til den definitive skade (døden). Som påpeget af Waaben, ${ }^{42}$ ) har man ikke, da straffeloven blev udarbejdet, været tilstrækkelig opmærksom på problemerne vedrørende risiko for formuetab. Man har valgt at kriminalisere følgen — for nogle af berigelsesforbrydelsernes vedkommende dog med fremrykkelse af fuldbyrdelsesmomentet.

Om man herefter burde overveje at kriminalisere forsætlig farefremkaldelse i forbindelse med berigelsesforbrydelserne, ${ }^{43}$ ) afhænger naturligvis af, om der kan påvises et behov herfor. At de ovenfor refererede underslæbsdomme ville være mindre knitisable, hvis der var dømt med hjemmel i en sådan regel, siger i sig selv intet om, hvorvidt der også burde eksistere et forsætligt faredelikt på området. Flere af forholdene synes at være så lidet strafværdige - set $i$ såvel special- som generalpræventiv belysning — at der end ikke burde være d $\phi \mathrm{mt}$ for forsætlig fareforvoldelse (se klarest UfR 1962.168 om pantefogden). Der b $\phi \mathbf{r}$ ikke skabos mulighed for, at flere af den type forhold påtales og $d \phi \mathrm{m}-$ mes efter straffeloven. ${ }^{44}$ ) Waaben understreger da også, at visse hensyn taler imod at sætte for vide nammer ved valget af ger-

41) Stephan Hurwitz: op.cit., p. 89.

41a) Stephan Hurwitz: op.cit., p. 249.

$\left.{ }^{42}\right)$ Knud Waaben: op.cit., p. 199.

43) Det skal bemærkes, at muligheden for kriminalisering af farefremkaldelse ikke er omtalt direkte i straffelovrådets udtalelse om økonomisk kriminalitet af 14. januar 1974. I udtalelsens forslag til § C gøros visse handlinger strafbare uafhængigt af, om der er indtrådt følger, men rådet er modstander af en sådan bestemmelse - vel ikke ud fra en opfattelse af den som et abstrakt faredelikt, men fordi de (samfunds-) farlige handlinger, den skulle ramme, ikke kan beskrives tilstrækkeligt præcist.

44) Derimod kan eventuelt bogføringsloven, lov nr. 178 af 5 . juni 1959 , komme på tale $\mathrm{i}$ visse tilfælde. 
ningsområde. „Betegnelserne underslæb og bedrageri er forbundet med en infamerende virkning fordi de først og fremmest omfatter personer med slette hensigter. Man må være varsom med at g $\phi \mathbf{r e}$ dem anvendelige overfor personer som ikke har ment at deres forhold rummede et egentligt angreb på andres formue. Der er ofte plads for tvivl om hvor forkastelig en handling er, og underslæbene glider jævnt over i nogle forhold, der kun kan kaldes sl $\varnothing$ seri, dårlig forretningsskik o. l.“45)

At der netop i forbindelse med underslab ofte foreligger specielle bevisproblemer på det subjektive plan i form af indviklede psykologiske forklarings- og fortrængningsmekanismer hos gerningsmændene, ${ }^{46}$ ) kunne rejse sp $\varnothing$ rgsmålet om en anden lovgivningsteknisk mulighed, nemlig en regel om (groft) uagtsomt underslæb, i lighed med den i straffeloven ved lov nr. 250 af 12. juni 1975 indf $\varnothing$ jede $\S 300$ a, der omfatter groft uagtsom forvoldelse af formuetab. Denne nye bestemmelse er et supplement til $\S 279$ om bedrageri - et område, hvor man i praksis i endnu højere grad, end for så vidt angår underslæb, synes at have givet op over for bevisproblemerne $\mathrm{i}$ forbindelse med berigelsesforsættet. De gerningsmænd, man søger at ramme med $\S 300 \mathrm{a}$, har imidlertid nok anderledes ,slette hensigter" end de kasserere, sogneog pantefogder, kommissionærer o. lign., der optræder som gerningsmænd i de ovenfor refererede underslæbssager. Selv om en bestemmelse om uagtsomt underslæb formentlig rent formelt ville være en holdbar hjemmel for afg $\phi$ relserne i de nævnte domme (bortset dog fra UfR $1957.649 \emptyset$ om sagf $\phi$ rerfuldmægtigen, idet en uagtsomhedsregel vel må kræve et faktisk påf $\phi$ rt formuetab), kan der næppe være præventive hensyn, der taler for ad denne vej at udvide underslæbsområdet til at omfatte personer med en ringe grad af kriminelt sindelag. ${ }^{47}$ )

Kravet om berigelsesforsæt, dvs. forsæet til vinding for sig selv og tab for offeret, b $\phi r$ opretholdes, og domstolene bør være tilbageholdende med at statuere et sådant forsæt i tvivlsomme tilfælde.

45) Knud Waaben: op.cit., p. 291.

46). Stephan Hurwitz: Spec. del, p. 417 med note 8. Donald R. Cressey: Other People's Money. A study in the social psychology of embezzlement, Glencoe, Ill., 1953.

47) Jfr. også Knud Waaben: op.cit., p. 291: „, Det er tænkeligt, at det $\phi$ konomiske liv $\mathrm{i}$ de senere årtier har gjort det til et st $\varnothing \mathrm{rre}$ problem end tidligere at overveje særlige straffebestemmelser til værn om formueinteresser mod forsætlig eller groft uagtsom farefremkaldelse. Men det er givet, at fors $\phi g$ på at formulere sådanne bestemmelser vil m $\varnothing \mathrm{de}$ stærke betænkeligheder". 
VII. Sammenfatning.

Det foregående indeholder en påvisning af det forhold, at domstolene i strid med straffelovens ordlyd og forarbejder dømmer for underslæb i tilfælde, hvor der ikke foreligger hensigt (direkte forsæt) til at bevirke en materiel formueforskydning, og at teorien synes at have accepteret denne retspraksis uden kritik.

Det fremhæves, at såfremt forskellige hensyn skulle tale for en sådan udvidelse af det subjektive krav til berigelsen, må det kritiseres, alt domstolene $\phi$ jensynligt ikke lader forsættets nedre grænse bestemme af den almindeligt antagne definition af forsæt til følger, men statuerer underslæb ved selv lave grader af risiko for tab. Ved visse domme kan det subjektive rekvisit kun dækkende betegnes som enten forsæt til fare eller bevidst uagtsomhed til skade.

Specielt kritiseres det, at der forekommer domme, hvor den tiltaltes handlemåde - objektivt såvel som i hans egen forestilling - overhovedet ikke synes at have rummet nogen risiko for den berettigede. Forholdet kan her være det, at domstolene er gået ud fra en fejlagtig retsopfattelse. Beviserne for tilstedeværelsen af en objektiv tabsrisiko eller for gerningsmandens subjektive indstilling hertil kan også være vurderet forkert. 